RAD Conference Proceedings, vol. 2, pp. 99-103, 2017

www.rad-proceedings.org

\title{
RADIATION HAZARDS AND RADIATION PROTECTION PRACTICES OBSERVED FROM DIFFERENT PERSPECTIVES
}

\author{
Stevan Musicki', Dejan Vasovic ${ }^{2 *}$, Srdjan Markovic3 \\ ${ }^{1}$ University of Defence, Military Academy, Belgrade, Serbia \\ ${ }^{2}$ University of Niš, Faculty of Occupational Safety, Niš, Serbia \\ 3Ministry of Defence, Department for General Logistics, Belgrade, Serbia
}

\begin{abstract}
The term of radiation hazards is connected to the hazardous levels of ionizing radiation that could be harmful to the living tissue. Reflecting the contemporary lifestyle the World Health Organization (WHO), stated that as the use of ionizing radiation increases, so does the potential for health hazards if not properly used or contained. The increased rate of ionizing radiation can be attributed to the variety of anthropogenic activities, ranging from ore extraction, medical services, and energy production to military installations. On the other hand, radiation protection practices term indicates the measures directed to the protection of humans, in the first place, and other living organism from the harmful effects of exposure to ionizing radiation. In that sense, efficient and effective radiation protection from the perspective of society usually involves minimizing costs and capital commitment in any way. On the other hand, effective and efficient radiation protection management activities from the perspective of the army involve broader radiation protection measures during peacetime, emergencies and even wartime. The aim of this paper is to help the development of an integrative review for radiation protection, addressing the contemporary needs within the different but prominent stakeholders: civil and military structures. The paper offers an in-depth analysis of related core terms: radiation protection principles and modalities of protection. The applied methodology consists of comparative structure analysis and evaluation of available data. Obtained results are intended to be used in further implementation processes regarding the radiation protection practices both in civil and military structures.
\end{abstract}

Key words: Radiation hazards, protection practices, civil structures, military structures, review

DOI: $10.21175 /$ RadProc.2017.21

\section{AIMS AND THE BACKGROUND}

A growing number of security risk, above all regional conflicts, terrorism, proliferation of the weapons of mass destruction, as well as other challenges, risks, and threats are becoming increasingly unpredictable, thus creating a need for adopting a National Security Strategy of the Republic of Serbia as the most important strategic document in the security system. As an integral part of the security system, the national security strategy has a civilian character and is based on coordination relations, contained within leadership and issuing of commands, with the features of hierarchic relationships in the sphere of system management [1].

Risks of emergencies caused by natural disasters and human activities are present in every society. Therefore, they require a comprehensive National Strategy for Protection and Rescue in Emergencies, which includes the systems for prevention, mitigation, protection, rescue, and recovery. The foundation for the adoption of the National Strategy is found in the Law on Emergencies which regulates the establishment of an integrated system of protection and rescue for the purpose of protecting citizens' lives, health, and property, as well as the environment and cultural heritage of Serbia [2].

In Serbia, emergencies are regulated by the law, while specific areas that could impact the environment and safety of citizens are regulated by separate laws. In addition to the Law on Emergencies, the core of the Serbian protection and rescue system also contains other laws harmonized with European Union (EU) regulations and other United Nations (UN) programme documents. [3]

The aim of this paper is to help the development of an integrative review for radiation protection, addressing the needs of different but prominent stakeholders: civilian and military structures, among others (ministry of interior, etc.).

\section{INSTITUTIONAL FRAMEWORK}

According to the Law on Emergencies, the protection and rescue system comprises the following system subjects:

\footnotetext{
*djnvasovic@gmail.com
} 
- state administration bodies, bodies of the autonomous provinces, and bodies of local self-government units;

- companies, other legal persons, and entrepreneurs; and

- citizens, groups of citizen groups, associations, and professional and other organizations.

According to the Law on Emergencies, the responsibility of emergency response lies with the protection and rescue forces, which comprise emergency response centres, civil protection units, fire and rescue units, the police, the military, and other subjects whose scope of activity includes rescue. A special role in protection and rescue system is played by the Serbian Radiation Protection and Nuclear Safety Agency, the Ministry of Internal Affairs, and the Ministry of Defence. The Law on Emergencies defines the jurisdictions of the ministries and other bodies and organizations involved in protection and rescue, which stems from the legal role the ministries play in accordance with their legal authority $[2,3]$.

\subsection{Serbian Radiation Protection and Nuclear Safety Agency}

Enacting the Law on Ionizing Radiation Protection and Nuclear Safety of Serbia, the Serbian Government established the Serbian Radiation Protection and Nuclear Safety Agency, as a stand-alone regulatory agency in the field of radiation protection and nuclear safety in Serbia [4].

For the purpose of conducting the operations within the established purview of the Agency, the following basic internal organizational units have been created:

- $\quad$ Sector for radiation safety and security;

- Sector for nuclear safety and security; and

- Sector for professional supervision and control of the work of licensed and authorized bodies, legal and financial operations, general operations, and public procurement operations.

The sector for radiation safety and security performs the following work:

- prepares the programme proposals for radiation safety and security;

- creates instructions and procedures required for the implementation of radiation safety and security measures;

- prepares the programme of systematic examination of environmental radioactivity;

- $\quad$ prepares the programme of prompt accident announcement;

- prepares the proposal of the accident response plan;

- monitors the scope and changes of radioactivity levels, assesses their impact on the population and the environment, and, accordingly, authorizes and supervises the implementation of required measures;

- cooperates with other state and international bodies regarding the response in the event of suspected accidents and actual accidents, as well as other protection and rescue activities [5].

\subsection{Ministry of Internal Affairs of the Republic of Serbia}

The Ministry of Internal Affairs of the Republic of Serbia organizes and implements activities related to the protection of citizens' lives, health, and property during emergencies through its Emergency Sector. The Ministry of Internal Affairs has a primary role in raising the capacities of the subjects of the emergency protection and rescue system [6]. The Emergency Sector was established through a reorganization of a portion of state administration bodies, involving a unification of the functions, employees, and property of the Protection and Rescue Sector with the Ministry of Internal Affairs, Emergency Administration of the Ministry of Defence, and parts of the organizational units of the Ministry of Environment, Mining and Spatial Planning.

The primary task of the Serbian Emergency Sector is to improve the risk prevention in order to mitigate the effects of various disasters that can hit the region. It unifies every existing resource for protection, rescue, and emergency response [6].

\subsection{Ministry of Defence and the Serbian Military} Forces

The Ministry of Defence and the Serbian Military do not develop any separate capacities for protection and rescue tasks, but use the existing capacities to support the authorities and protection and rescue organizations if necessary.

In case of an emergency due to natural or other accidents and disasters, portions of the Serbian Military can be put on stand-by and utilized on the orders of the Chief of the General Staff of the Serbian Military or another officer in charge, under the authority of the Serbian President.

For protection and rescue operations, the Ministry of Defence and the Military capacities of logistical support, air force, engineer corps, and Chemical, Biological, Radioactive, and Nuclear Defence (CBRND) units. CBRND units are diverse organizational units of the CBRND military branch. They are equipped and trained to take special CBRN security measures within the designed CBRND system, either on their own or as parts of other structures, either using their separate units or as a whole, in all of Serbia.

Serbia has expressed its intent regarding CBRND through the Partnership for Peace (PfP), more specifically, through the presentation document: "The Republic of Serbia wishes to improve and promote its national capabilities for protection against radiological, nuclear, biological, and chemical weapons threats, as well as consultation and coordination of activities in the field with PfP partner countries and North Atlantic Treaty Organization (NATO) Members. The Serbian Military centre for personnel training and improvement represents a national point of reference in the planning of the development of regional and broader international significance. Concurrently, this development includes training, joint international engagement of teams, instruction of national mobile training teams and instructors, as well as support to civilian authorities both at home and in the NATO and PfP countries [7]. 
The operations of the CBRND service involve the CBRND measures on the level of tactical unit, the socalled general CBRN security measures, and on the level of CBRND units, the so-called special Chemical, Bilogical, Radioactive, Nuclear (CBRN) security measures. For their expert field of operations, the CBRN service system of the Serbian Military uses the capacities of the Military Technical Institute, the Technical Testing Centre, and the National Poison Control Centre with the Military Medical Academy, as well as capacities of civilian institutions.

An important role for the successful functioning of the CBRN service is played by the CBRND Centre, through its performance of the following tasks:

- $\quad$ individual training (with personal instructor) and certification of individual training of the CBRN service;

- organization of courses of different levels for the purposes of the Serbian Military, CBRND courses for the civilian structures of the Serbian Government, international courses for foreign armed forces and international organizations;

- creation of instructions, rules, and procedures;

- provision of expert assistance in the field of CBRND to the structures within or outside the Ministry of Defence;

- provision of support for: fulfilment of international obligations of Serbia (Chemical Weapons Convention, Biological Weapons Convention, Weapon of Mass Destruction (WMD) Non-Proliferation Treaty), scientific research in the field of CBRND, and testing of CBRND equipment.

To meet the needs of the Emergency Sector with the Ministry of Internal Affairs of the Republic of Serbia, the Centre organizes training for the radiological, chemical, and biological (RCB) civil defence units, as well as training and education for the purpose of:

- the Organization for the Prohibition of Chemical Weapons ban (Assistance and Protection Branch and the Inspectorate of the Technical Secretariat);

- countries in the region;

- $\quad$ interested NATO and PfP members; and

- $\quad$ other interested countries based on bilateral agreements.

The CBRND Centre, in cooperation with the Emergency Sector with the Ministry of Internal Affairs of the Republic of Serbia, participates in the creation of the unit's organizational structure and the model for equipping it, based on which the units for other Serbian cities were created and equipped.

In order to further improve CBRND in Serbia, the Ministry of Defence has signed several international treaties:

- bilateral agreement concerning WMD nonproliferation between the United states and Serbia;

- long-term cooperation agreement with the Organization for the Prohibition of Chemical Weapons.

- Cooperation in the field of CBRND has been established with:
- the Ministry of Defence of the Czech Republic and

- the Ministry of Defence of the Republic of Austria.

Serbian Armed Forces CBRN Centre represents a national point of reference in the planning of the development of regional and broader international significance. Concurrently, this development includes training, joint international engagement of teams, instruction of national mobile training teams and instructors, as well as support to civilian authorities both at home and in the NATO and PfP countries. Its operative unit is $246^{\text {th }} \mathrm{CBRN}$ Battalion, located in the city of Kruševac. The position of $246^{\text {th }}$ CBRN Battalion within the Serbian armed forces (SAF) is shown on Figure 1.

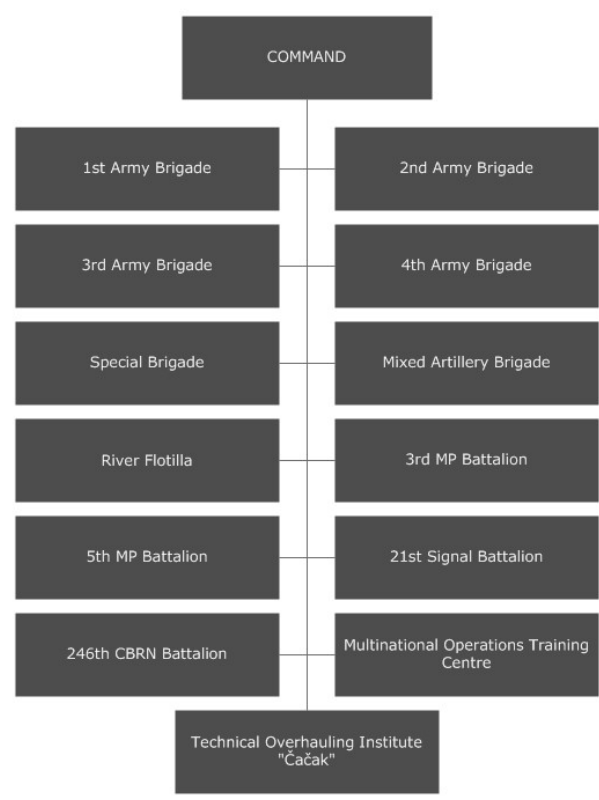

Figure 1. The position of $246^{\text {th }}$ CBRN Battalion within the SAF [8]

On the November 06, 2013 Serbian Minister of Defence signed the Decision on organizational transformation and development of the CBRN Personnel Advancement Centre into the Regional CBRN Training Centre. The structural and organizational transformations related with adjustment of organizational structure, missions and tasks as Regional Centre. After fulfilling these changes, Centre has officially changed name into Chemical-Biological-Radiological-Nuclear Centre (CBRN Centre), the structure of which is shown in Figure 2. 


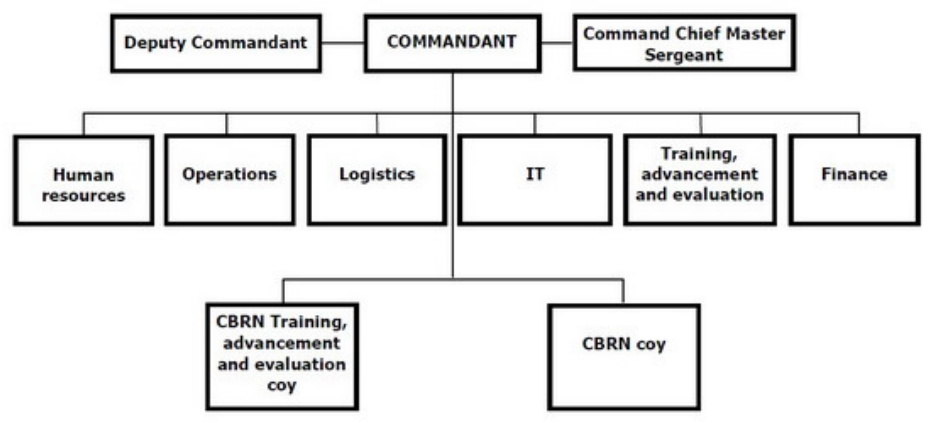

Figure 2. The structure of the regional CBRN centre [8]

\section{CONCLUSION}

The national, cross-sectoral approach to radiation safety has to be clearly and unequivocally defined in order to motivate and instigate the taking of necessary actions in the right direction, strategic development, and the time frame.

The main goal is to create conditions for building a society resilient to disasters by developing an integrated and efficient protection and rescue system in Serbia. In keeping with the National Sustainable Development Strategy, it is necessary to:

- harmonize national legislation concerning protection against ionizing and non-ionizing radiation with EU legislation and IAEA regulations;

- $\quad$ resolve the issue of radioactive waste storage;

- design and upgrade the system for the monitoring of radioactivity and non-ionizing radiation, the information system, data bases, and the system for emergency notification and response;

- strengthen the personnel, technical, and organizational aspects on all levels when implementing protective measures against ionizing and non-ionizing radiation.

Integrated and effective protection and rescue civilmilitary system implies the need to re-build common capacities and establish standard operating procedures within civil - military cooperation. Such co-operation implies certain means like a joint body with the task stewarded both to preventative measures and modalities of protection against the radiation (during the peace-time, war or natural and man-made emergencies). These activities leads to determination of roles, responsibilities and capacities of the Serbian Army and more accurate measures when and to what extent the Serbian Army should be included within such activities like the radiation protection as well as mitigation of consequences caused by radiation.

A developed, comprehensive, efficient, and effective system for the reduction of risks and consequences of natural disasters and other accidents related to radiation hazards through integrated emergency management in Serbia contributes to increased security and sustainable development in the region.
Acknowledgement: The presented research is done as a part of the research activities within projects "Development of new information and communication technologies, based on advances mathematical methods, with applications in medicine, telecommunications, power systems, protection of natural heritage and education" (III 44006) and "Research and development of energy efficient and environment friendly polygeneration systems based on renewable energy sources utilization" (III 42006), under the auspices of the Ministry of Education, Science and Technological Development, Republic of Serbia.

\section{REFERENCES}

1. Министарство одбране Републике Србије. (1.04.2009). Стратегија националне безбедности Републике Србије. (Ministry of Defence of Republic of Serbia. (Apr. 1, 2009). National security strategy of the Republic of Serbia.).

Retrieved from:

http://www.mod.gov.rs/multimedia/file/staticki sadrz aj/dokumenta/strategije/Strategija\%2onacionalne\%20 bezbednosti\%20Republike\%20Srbije.pdf

Retrieved on: Dec. 15, 2016

2. Народна скупштина Републике Србије. (6.10.2012). Бр. 93/2012 Закон о ванредним ситуацијама. (National Assembly of the Republic of Serbia. (Oct. 6, 2012) No. 93/2012 Law on emergency situations.)

Retrieved from:

http://prezentacije.mup.gov.rs/svs/html/Zakon\%200\% 20VS.pdf

Retrieved on: Dec. 15, 2016

3. Народна скупштина Републике Србије. (18.11.2011). Бр. 86/2011 Национална стратегија заштите и спасаванја у ванредним ситуацијама. (National Assembly of the Republic of Serbia. (Nov. 18, 2011) No. 86/2011 National strategy for protection and rescue procedures in emergency situations.)

Retrieved from:

http://www.rsjp.gov.rs/malodrvo/bazastrategija/2 jav na bezbednost $/ 2 \quad 4$ nacionalna strategija zatite i s pasavanja u vanrednim situacijama/2.4 nacionalna strategija zastite i spasavanja u vanrednim situac ijama.pdf

Retrieved on: Dec. 15, 2016

4. Народна скупштина Републике Србије. (28.09.2012). Бр. 93/2012 Закон о заштити од јонизујућеа зрачења и нуклеарној сигурности. (National Assembly of the Republic of Serbia. (Sep. 28. 2012) 
No. 93/2012 Law on the ionizing radiation protection and nuclear safety.)

Retrieved from:

http://www.mpn.gov.rs/wp-

content/uploads/2015/08/zastita jonizujuca zracenja nuklearna sigurnost cir.pdf

Retrieved on: Dec. 15, 2016

5. Званични сајт Агенције за заштиту од јонизујућег зрачења, Агенција за заштиту од јонизујућег зрачења, Београд, Србија. (Official website of the Agency for Ionizing Radiation Protection, Belgrade, Serbia.)

Retrieved from: http://www.srbatom.gov.rs/srbatom/ Retrieved on: Dec. 16, 2016

6. Организациона шема сектора за ванредне ситуације, Министарство унутрашњих послова Републике Србије, Београд, Србија. (Organizational scheme of the Sector for emergency situations, Ministry of the interior, Belgrade, Serbia.)

Retrieved from:

http://prezentacije.mup.gov.rs/svs/HTML/organizacij a.html

Retrieved on: Dec. 16, 2016
7. Foto Duro, "Serbia - NATO defence cooperation," Belgrade Centre for Security Policy, Belgrade, Serbia, 2015.

Retrieved from:

http://www.bezbednost.org/upload/document/natoserbia police coop \% ${ }_{5}$ Bweb\% $\%$ D.pdf

Retrieved on: Dec. 16, 2016

8. Организација u структура Копнене војске Републике Србије, Команда Копнене војске РC, Ниш, Србија. (Organization and structure of Serbian Army, Serbian Army Command, Niš, Serbia.)

Retrieved from:

http://www.vs.rs/index.php?content=7bc6bb5d-f71a102b-bdc2-a0672172d7df

Retrieved on: Dec. 16, 2016 